\title{
Imagini hidroaerice pulmonare multiple - capcane de diagnostic, prezentare cazuri clinice
}

\author{
Simona-Ştefania Dobre ${ }^{1,2}$, Simin-Aysel Florescu ${ }^{1,2}$, Petre lacob Calistru ${ }^{1,2}$, \\ Maria Nica ${ }^{1,2}$, Alma Kosa ${ }^{1}$ \\ ${ }^{1}$ Spitalul Clinic de Boli Infecţioase şi Tropicale „Dr. Victor Babeş“, Bucureşti, România \\ Universitatea de Medicina şi Farmacie "Carol Davila", Bucureşti, România
}

\begin{abstract}
REZUMAT
Leziunile cavitare pulmonare pun probleme complexe de diagnostic diferenţial, spectrul etiologic incluzând: - Infecţii necrotizante (pneumonii, tuberculoză pulmonară, abcese cu paraziţi şi fungi) sau

- Afecţiuni noninfecţioase (neoplasm pulmonar necrozat, infarct pulmonar infectat, vasculite, colagenoze cu cavităţi pulmonare prin mecanism imunologic, aspiraţie de corp străin intrabronşic, malformaţii congenitale pulmonare, pneumoconioze excavate etc).

Prezentăm trei cazuri clinice cu imagini radiologice similare, respectiv multiple formaţiuni cavitare pulmonare, dar cu diagnostic şi etiologii diferite: sepsis cu Staphilococcus aureus MRSA, echinococoza cu localizări multiple şi tuberculoză pulmonară secundară, formă cazeos-cavitară.

În toate cele trei cazuri, radiografia pulmonară standard a fost investigaţia de bază în diagnosticul afecţiunii pulmonare, însă diagnosticul de certitudine a necesitat efectuarea şi altor metode de investigaţie.
\end{abstract}

Cuvinte cheie: pneumatocele, echinococoză pulmonară, tuberculoză pulmonară secundară

\section{INTRODUCERE}

Leziunile cavitare pulmonare pun probleme complexe de diagnostic diferenţial, spectrul etiologic incluzând:

- Infecţii necrotizante (pneumonii, tuberculoză pulmonară, abcese cu paraziţi şi fungi) sau

- Afecţiuni noninfecţioase (neoplasm pulmonar necrozat, infarct pulmonar infectat, vasculite, colagenoze cu cavităţi pulmonare prin mecanism imunologic, aspiraţie de corp străin intrabronşic, malformaţii congenitale pulmonare, pneumoconioze excavate etc).

\section{PREZENTAREA CAZURILOR}

\section{Pacient 1}

Primul caz este cel al unui pacient în vârstă de 43 ani, fumător (35 pachete/an), consumator de droguri injectabile de la vârsta de 14 ani (heroină şi etnobotanice), care se prezintă pentru febră, junghi toracic anterior şi astenie progresivă. Din anamneză reţinem junghi toracic, localizat la nivelul hemitoracelui drept, cu iradiere posterioară, fără poziţie antalgică, şi care se accentua la mişcare şi efort fizic, debutat cu aproximativ 6 luni înainte de internare şi cu accentuare progresivă; astenie fizică, apărută cu o saptămână înainte de internare, cu agravare progresivă, până la slăbiciune musculară severă, deficit motor, imposibilitatea deplasării; iar în ultimele trei zile anterior internării pacientul prezintă febră, frison şi dispnee progresivă.

Din antecedentele personale patologice notăm hepatită cronică cu virus hepatitic $\mathrm{C}$, diagnosticată în urmă cu aproximativ un an şi jumătate în urma unui examen de laborator, şi multiple abcese dentare în ultimul an, autotratate de pacient cu Augmentin.

Pacientul este caz social: fără domiciliu şi fără ocupaţie. 
Examenul obiectiv în momentul internării a evidenţiat pacient subponderal $(\mathrm{G}=59 \mathrm{Kg}, \mathrm{T}=175 \mathrm{~cm}$, $\mathrm{BMI}=19,5) \mathrm{cu}$ stare de conştienţă alterată, tegumente si mucoase palide, febril $\left(\mathrm{T}=38,7^{\circ} \mathrm{C}\right)$, pulmonar stetacustic prezenţa de raluri bronşice ronflante şi crepitante bilateral, predominant bazal dreapta, $\mathrm{Sa} \mathrm{O}_{2}=96 \%$ în aer atmosferic, $\mathrm{AV}=96 /$ $\min , \mathrm{TA}=100 / 70 \mathrm{mmHg}$.

Investigaţiile efectuate la internare au indicat: leucocitoză importantă cu neutrofilie $(\mathrm{L}=18.400 /$ $\mu 1$, neutrofile $=91,8 \%$ ), trombocitopenie (trombocite $=88.700 / \mu \mathrm{l})$, sindrom inflamator $(\mathrm{VSH}=75$ $\mathrm{mm} / \mathrm{h}, \mathrm{CRP}=15,6 \mathrm{mg} / \mathrm{dl}$, Procalcitonina pozitivă $=$ $10 \mathrm{mg} / \mathrm{dl})$, hiponatremie $\mathrm{cu}$ hipopotasemie $(\mathrm{Na}=$ $121 \mathrm{mmol} / \mathrm{L}, \mathrm{K}=3,2 \mathrm{mmol} / \mathrm{L}$ ); bilanţul virusologic a evidenţiat $\mathrm{Ag} \mathrm{HB}_{\mathrm{s}}$ negativ, AcAnti $\mathrm{HVC}$ pozitiv, AcAnti HIV negativ.

S-au recoltat hemoculturi care s-au pozitivat la 2 zile de la internare pentru Staphilococcus aureus, tulpina MRSA pozitivă, cu rezultatul antibiogramei.

Radiografia pulmonară standard evidenţiază: multiple opacităţi cu caracter alveolar, unele omogene, altele cu nivele hidroaerice (pneumatocele), proiectate difuz bilateral predominant pe partea dreaptă, laterotoracic, cu diametre cuprinse între 1 şi $5 \mathrm{~cm}$, sugestive pentru stafilococie pulmonară (Fig. 1).

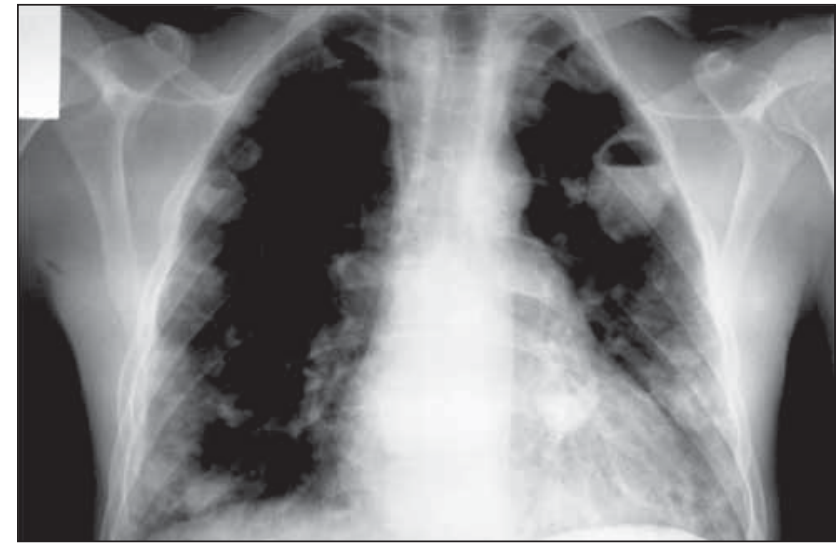

FIGURA 1. Aspect radiologic pacient 1 - Pneumatocele

Date fiind rezultatele de laborator şi examenul radiologic, bilanţul investigaţional a fost completat cu alte explorări imagistice.

Ecocardiografia transtoracică descrie formaţiuni mobile de 8 şi $17 \mathrm{~mm}$ la nivelul valvei aortice, cu aspect de vegetaţii, cavitate VS normală cu funcţie sistolică globală şi segmentară normale.

Examenul computer tomograf toraco-abdominal cu substanţă de contrast a arătat: multiple leziuni rotund-ovalare, bine delimitate, cu aspect chistic, având perete discret îngroşat circumferenţial şi conţinut fluid, cu incluziuni gazoase, unele apărând complet evacuate, cu conţinut aeric, la nivelul am-

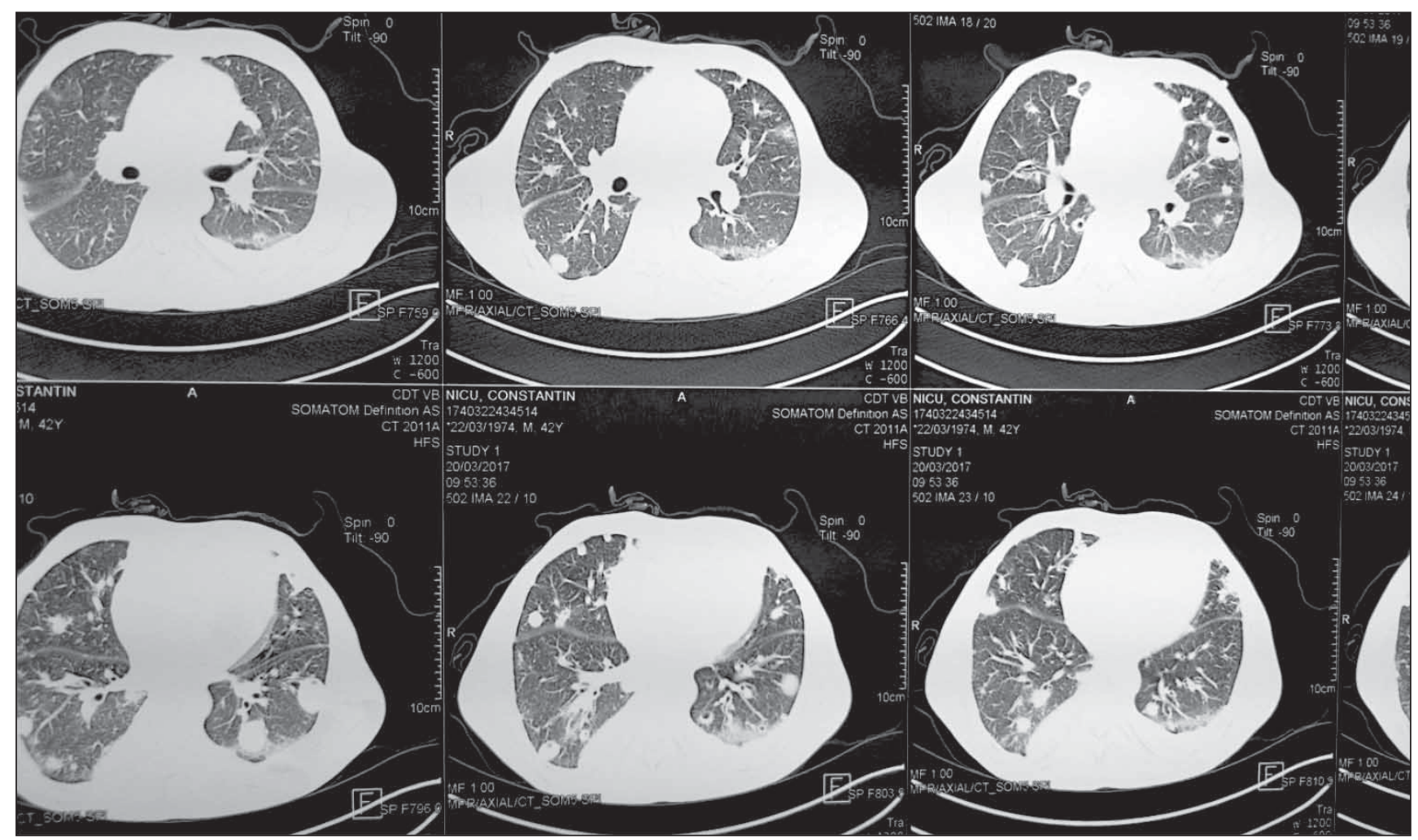

FIGURA 2. Tomografie toracică pacient 1 - Pneumatocele. Revărsat pleural bilateral. 
bilor plămâni, cele mai mari având diametrul 22 mm pe partea dreaptă şi $55 \mathrm{~mm}$ pe partea stângă; revărsat lichidian liber şi parţial cloazonat la nivelul ambelor cavităţi pleurale având grosime maximă $26 \mathrm{~mm}$ în dreapta şi $28 \mathrm{~mm}$ pe partea stângă (Fig. 2).

Pe baza anamnezei, datelor clinice, paraclinice şi imagistice, s-a conturat diagnosticul pozitiv de sepsis sever cu Staphilococcus aureus - tulpină MRSA, endocardită infecţioasă cu MRSA cu determinări septice pulmonare la un pacient cu hepatită cronică cu virus hepatitic C, toxicomanie cu etnobotanice.

\section{Pacient 2}

Al doilea caz este cel al unei paciente în vârstă de 47 ani, provenind din mediul rural, casnică, cunoscută cu astm bronşic uşor persistent, urmând tratament intermitent cu corticosteroizi inhalatori şi beta 2 agonişti de lungă durată, care se prezintă în clinică pentru tuse seacă de 2 luni, cu apariţia expectoraţiei seromucoase în ultima săptămână.

Examenul clinic general nu evidenţiază nimic patologic la nivelul aparatului respirator.

Radiografia pulmonară de faţă decelează mai multe opacităţi nodulare în ambele câmpuri pulmonare, cu predominenţă în câmpul pulmonar drept, două dintre ele având nivel hidroaeric (Fig. 3).

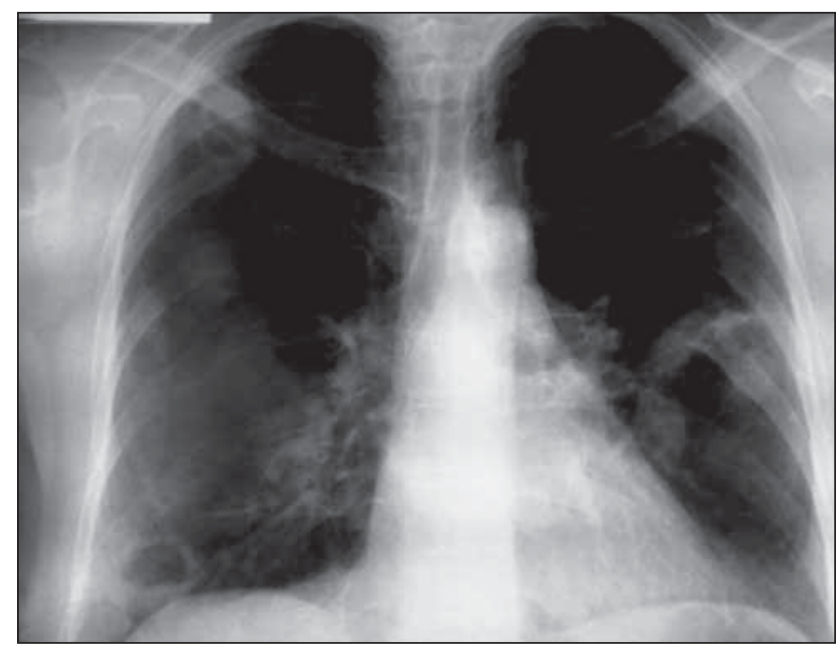

FIGURA 3. Radiografie pulmonară pacient 2. Imagini hidroaerice diseminate în ambele câmpuri pulmonare cu predominență dreapta - Hidatidoză pulmonară

Se efectuează bronhoscopie, care nu pune în evidenţă modificări endoluminale bronşice în teritoriul studiat, iar lavajul bronhoalveolar efectuat arată o celularitate cu predominenţa eozinofilelor, fără a se găsi celule maligne. Coloraţiile Ziehl-Neelsen efectuate din lavaj sunt negative pentru bacili acid alcolorezistenţi; se însămânţează cultura pentru BK din aspiratul bronşic pe mediul lichid (metoda $\mathrm{MB} /$ BacT-Alert), cu rezultat negativ.

Datele de laborator evidenţiază leucocitoză cu eozinofilie marcată (leucocite $=14.300 / \mu 1$, eozinofile $=9.337 / \mu \mathrm{l}=15,3 \%$ ), sindrom inflamator biologic $(\mathrm{VSH}=68 \mathrm{~mm} / \mathrm{h}, \mathrm{CRP}=2,35 \mathrm{mg} / \mathrm{dl}$, fibrinogen $=572 \mathrm{mg} / \mathrm{dl}$ ), hemoculturi negative şi serologie pozitivă pentru Echinococus granulosus. În acest context se renunţă la biopsia transtoracică, în vederea diagnosticului diferenţial din cauza posibilelor consecinţe nefavorabile (şoc anafilactic, hidatidoză secundară).

Diagnosticul pozitiv a fost de chisturi hidatice pulmonare multiple.

Se efectuează investigaţii suplimentare pentru depistarea unor eventuale alte localizări viscerale. Ecografia abdominală evidenţiază trei formaţiuni transonice, rotund-ovalare, cu diametre maxime de $1,4 \mathrm{~cm}, 2,5 \mathrm{~cm}$ şi $5 \mathrm{~cm}$, contur neregulat, cu fine septe în interior, situate la nivelul segmentelor IV şi VI hepatice, sugestive pentru echinococoza hepatică. Diagnosticul final a fost de echinococoză cu localizări multiple sincrone, hepato-pulmonare.

\section{Pacient 3}

Este vorba de un pacient în vârstă de 58 ani, mare fumător (40 pachete/an), care se adresează în ambulatoriul de specialitate pentru simptomatologie debutată cu 2 luni înainte, respectiv tuse iniţial seacă, astenie marcată, iar cu o saptămână înainte de prezentare tuse cu expectoraţie mucopurulentă, intermitent hemoptoică şi subfebră.

La prezentare, pacient subponderal, afebril, tegumente şi mucoase palide, pulmonar la auscultaţie raluri ronflante axilar dreapta, $\mathrm{SaO}_{2}=97 \%$ în aer atmosferic.

Biologic se evidenţiază leucocitoză uşoară (leucocite $=11.200 / \mu 1)$, anemie uşoară, hipocromă $(\mathrm{Hb}$ $=10,3 \mathrm{~g} / \mathrm{dl})$, hiperglicemie $($ glicemie $=168 \mathrm{mg} / \mathrm{dl})$.

La radiografia pulmonară standard se vizualizează două imagini cavitare, rotund-ovalare, cu perete neregulat, înglobate într-o zonă de leziuni infiltrative şi fibroase, ocupând lobul superior drept (Fig. 4). 


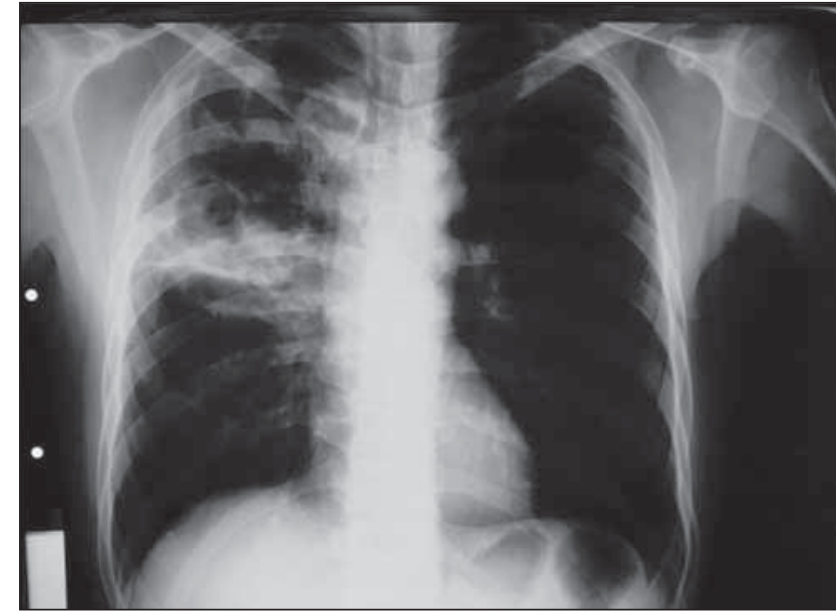

FIGURA 4. Radiografie pulmonară pacient 3. Leziuni fibro-cavitare lob superior drept

Existând suspiciunea clinico-radiologică de tuberculoză pulmonară se efectuează examen spută; metoda rapidă GeneXpert a detectat ADN - Mycobacterium tuberculosis, cu sensibilitate la RMP. Diagnosticul pozitiv a fost de tuberculoză pulmonară secundară, formă fibrocazeos-cavitară.

\section{DISCUTुII}

Cazurile prezentate suscită interes prin problematica de stabilire a diagnosticului etiologic; diagnosticul precoce are o mare importanţă practică, deoarece permite instituirea la timp a tratamentului care poate opri evoluţia procesului patologic.

Chistul hidatic $(\mathrm{CH})$ este o boală parazitară produsă de Taenia echinococcus granulosus, frecvent întâlnită în ţară noastră (1). Indicele de morbiditate în România varia în anii 1953-1963 între 5 şi 7 la 100.000 de locuitori. În perioada 1991-1995 s-au raportat aproape 1.000 de cazuri noi pe an, iar indicele de mortalitate a oscilat între 5 şi 7\%. Incidenţa cazurilor în România este mai mare în Dobrogea şi în zona centrală (1).

În România, echinococoza are caracter endemic. Cea mai frecventă localizare este cea hepatică (60\%), urmată de cea pulmonară. Echinococoza pluriviscerală este definită ca prezenţa concomitentă sau succesivă a hidatidozei în mai mult de un organ (2). S-a remarcat că numărul cazurilor de chisturi hidatice multiple şi cu localizări pluriviscerale a crescut în ultimii ani (3). În literatură incidenţa chistului hidatic cu localizări multiple variază între 0,2 şi $2 \%$, în funcţie de diverşi autori şi de zona endemică (4). Actualmente, pe plan mondial, se consideră că, în medie, din 100 cazuri de hida- tidoză umană, 5,1 cazuri se termină cu deces, 18,8 cazuri necesită intervenţii chirurgicale repetate, iar 76,1 pacienţi sunt trataţi medicamentos timp de ani de zile (5).

Chistul hidatic pulmonar, parţial evacuat şi suprainfectat, poate evolua cu imagini radiologice echivoce pentru acest diagnostic.

Diagnosticul diferenţial al supuraţiei pulmonare după vomică şi descoperirea imaginii hidroaerice trebuie să excludă cavităţile pleuropulmonare de altă natură (cavernă tuberculoasă, cancer excavat, chist aerian, bronşiectazie, empiem interlobar, fistulizat în bronhii), care se deosebesc prin antecedente, evoluţie, context clinic şi datele investigaţiilor complementare.

Dintre cauzele infecţioase bacteriene, în pneumonia stafilococică, leziunile cele mai caracteristice sunt imaginile cavitare multiple, cu prezenţa de nivel hidroaeric (pneumatocele).

Tuberculoza pulmonară se poate complica cu o stafilococie pleuro-pulmonară, crescând dificultatea şi complexitatea diagnosticului etiologic, modulând atitudinea terapeutică. Probarea etiologiei stafilococice prin examene bacteriologice adecvate rezolvă problema de diagnostic, dar nu exclude posibilitatea coexistenţei bolii cu alte afecţiuni pulmonare anterioare suprainfectate $\mathrm{cu}$ stafilococ.

Tuberculoza pulmonară este o altă entitate patologică ce poate avea drept imagine radiologică cavităţi pulmonare cu sau fără nivel hidroaeric. România este ţara Uniunii Europene cu cea mai mare incidenţă a tuberculozei (de 4 ori peste media UE). Totuşi, în ultimii ani, s-au înregistrat progrese importante în controlul acestei boli; incidenţa globală scăzând cu 49,8\% (de la 142,2\%ooo în 2002 la 71,7\%ooo în 2016) (6).

Pe baza examenului radiologic s-a ridicat suspiciunea de tuberculoză pulmonară. Diagnosticul de certitudine s-a stabilit pe baza examenului bacteriologic folosind tehnica moleculară de hibridizare liniară, conform ghidurilor actuale $\operatorname{OMS}(7,8,9)$.

În cazul prezentat, diagnosticul de laborator s-a stabilit cu ajutorul testării Xpert MTB/RIF, un test rapid de diagnostic, ce permite în mai puţin de 2 ore atât detectarea cazurilor de tuberculoză cât şi testarea rezistenţei la rifampicină, permiţând astfel medicului să stabilească decizia terapeutică corectă şi în timp minim.

Testul Xpert MTB/RIF, utilizând sistemul Cepheid GeneXpert ${ }^{\mathbb{B}}$, este un test complet automa- 
tizat de diagnostic PCR semicantitativ, în timp real in vitro, pentru: 1) detectarea ADN de Mycobacterium tuberculosis în probe de spută sau sedimente concentrate din sputa indusă şi 2) detectarea rezistenţei la rifampicină (mutaţii asociate ale genei rpoB) (10).

Ca principiu, sistemul GeneXpert Dx integrează şi automatizează procesarea probelor, amplificarea acidului nucleic şi detectarea secvenţei-ţintă de ADN, în probe simple sau complexe utilizând PCR în timp real şi revers-transcriptaza PCR. Sistemul necesită utilizarea cartuşelor GeneXpert de unică folosinţă care deţin reactivii PCR şi găzduiesc procesul PCR. Deoarece cartuşele sunt autonome, contaminarea încrucişată între eşantioane este eliminată (10).

Xpert MTB/RIF include reactivi pentru detectarea tuberculozei şi a rezistenţei RIF, precum şi un control al procesului de eşantionare (SPC) pentru prelucrarea adecvată a bacteriilor-ţintă şi monitorizarea prezenţei inhibitorului (inhibitorilor) în reacţia PCR (10).

\section{CONCLUZII}

Trăsătura comună tuturor cazurilor prezentate este aspectul radiologic monomorf ce contrastează cu polimorfismul etiologic.

Diagnosticul diferenţial al formaţiunilor cavitare pulmonare este adesea laborios, implicând numeroase proceduri: imagistice (radiografie convenţională, tomografie computerizată cu substanţă de contrast), bronhoscopie cu lavaj bronhoalveolar, biopsie transbronşică, biopsie transtoracică, teste serologice şi imunologice, investigaţii microbiologice.

Radiografia pulmonară convenţională rămâne una dintre metodele de bază în diagnosticul afecţiunilor pulmonare, dar uneori necesită suplimentarea cu alte metode de investigaţie cu acurateţe mai ridicată, menite să orienteze spre diagnosticul de certitudine. 